\title{
POTENSI PENGEMBANGAN TEMPAT CUCI TANGAN OTOMATIS SEBAGAI PENCEGAHAN COVID-19 DI DESA DANGIN PURI KANGIN
}

\section{THE POTENTIAL OF DEVELOPING AUTOMATIC HANDWASHING AS A PREVENTION OF COVID-19 IN THE VILLAGE OF DANGIN PURI KANGIN}

\author{
Komang Hernawan ${ }^{1)}$, I Komang Agus Ariana ${ }^{2)}$ \\ ${ }^{1,2}$ Universitas Pendidikan Nasional \\ ${ }^{1}$ Email: awanpnb@gmail.com
}

\begin{abstract}
Abstrak: Dalam mencegah penularan Covid-19 pemerintah sudah menghimbau kepada masyarakat untuk melakukan protokol Kesehatan antara lain menggunakan masker, menjaga jarak dan mencuci tangan. Di Desa Dangin Puri Kangin rata-rata untuk tempat umumnya sudah memiliki fasilitas tempat cuci tangan. Permasalahnnya disini terletak pada resiko penularan akibat sentuhan langsung pada gagang kran karena penggunaan banyak orang. Untuk itu diperlukan inovasi berupa pengembangan tempat cuci tangan biasa menjadi otomatis. Tujuan dari pengembangan ini yaitu untuk memanfaatkan teknologi dalam meminimalisir penularan Covid-19 serta manfaatnya dapat dirasakan oleh mahasiswa, perguruan tinggi dan masyarakat. Untuk mewujudkan inovasi ini, perlu dilakukan beberapa metode antara lain pengamatan lapangan, sosialisasi dan pengarahan cara mengaplikasikan tempat cuci tangan otomatis ini kepada masyarakat. Hasil dari kegiatan ini yaitu masyarakat lebih memahami manfaat mencuci tangan di tempat umum selama pandemi ini. Kemudian masyarakat dapat memperoleh pengetahuan tentang cara mengembangkan tempat cuci tangan menjadi otomatis untuk di aplikasikan di lingkungan sekitar. Kesimpulan yang dapat diperoleh dari kegitan ini yaitu tempat cuci tangan bisa dikembangkan menjadi otomatis untuk meminimalisir penularan Covid-19.
\end{abstract}

Kata Kunci: Potensi pengembangan tempat cuci tangan otomatis

Abstract: In preventing the transmission of Covid-19, the government has urged the public to carry out health protocols such as using masks, keeping their distance and washing their hands. In Dangin Village Puri Kangin the average for a public place already has a handwashing facility. The problem here lies in the risk of transmission due to direct touch on the handle of the faucet due to the use of many people. Therefore, innovation is needed in the form of the development of ordinary handwashing places to be automated. The purpose of this development is to utilize technology in minimizing the transmission of Covid-19 and its benefits can be felt by students, universities and the community. To realize this innovation, several methods are needed, including field observation, socialization and direction on how to apply this automatic handwashing place to the community. The result of this activity is that the public better understands the benefits of washing hands in public places during this pandemic. Then the community can gain knowledge on how to develop a handwashing place to be automatically presented in the surrounding environment. The conclusion that can be obtained 
from this kegitan is that handwashing can be developed into automatic to minimize the transmission of Covid-19.

Keywords: Potential development of automatic handwashing place

\section{PENDAHULUAN}

Covid-19 merupakan penyakit baru yang dapat menyebabkan gangguan pernafasan dan radang paru-paru. Penyakit ini disebabkan oleh infeksi Severe Acute Respiratory Syndrome Coronavirus. Gejala yang ditimbukan berupa flu biasa (batuk, pilek, nyeri tenggorokan, nyeri otot, dan nyeri kepala sampai ke komplikasi berat (DISKOMINFOTIK, 2020). Menurut data dinas Kesehatan Provinsi Bali 19 Februari 2021 terdapat 31.983 orang positif, 2674 orang dalam perawatan, 28.449 orang sembuh dan 860 orang meninggal (www.diskes.baliprov.go.id). Khusus Denpasar yang terdiri dari 27 desa temasuk Desa Dangin Puri Kangin terdapat 131 orang positif, 151 orang sembuh dan 2 orang meninggal (dinkes.denpasarkota.go.id).

Dalam pencegahan penularan Covid-19, masyarakat di himbau untuk menggunakan masker, menjaga jarak serta mencuci tangan setiap mengunjungi suatu tempat. Dalam pelaksaannya, beberapa masyarakat masih belum maksimal dalam mengikuti protokol kesehatan dalam hal mencuci tangan saat berada di tempat umum. Beberapa tempat umum sudah disediakan fasilitas tempat cuci tangan namun kesadaran masyarakat masih perlu ditingkatkan lagi. Disisi lain tempat cuci tangan secara biasa bisa dikatakan belum sepenuhnya aman digunakan karena masih ada resiko bersentuhan di area gagang kran karena penggunaan banyak orang. Untuk itu diperlukan suatu inovasi untuk meminimalisir penyebaran Covid-19 yang angka penyebarannya semakin meningkat. Dalam hal ini diperlukan peran dari berbagai golongan masyarakat seperti pemerintah, perguruan tinggi dan warga setempat. Untuk perguruan tinggi memiliki suatu program yang dikhususkan untuk membantu menyelesaikan masalah di lingkungan sekitar yang disebut KKN (Kuliah Kerja Nyata).

Kuliah Kerja Nyata merupakan bentuk pengabdian kepada masyarakat oleh mahasiswa dengan melakukan pendekatan lintas keilmuan dan sektoral pada waktu dan daerah tertentu. Sehubungan dengan masa pandemi saat ini, mahasiswa 
dapat membantu masyarakat dalam bidang invonsi untuk mencegah penularan Covid-19. Fasilitas penanganan Covid-19 seperti tempat cuci tangan di tempat umum bisa dikembangkan menjadi otomatis dengan tujuan untuk meminimalisir dampak sentuhan langsung saat pemakaian.

Dengan pembuatan tempat cuci tangan otomatis ini diharapkan agar masyarakat khususnya di Desa Dangin Puri Kangin dapat sepenuhnya terhindar dari virus yang menempel pada gagang kran dan membiasakan diri untuk mencuci tangan di tempat umum. Selain itu dengan pembuatan tempat cuci tangan ini bisa digunakan sebagai bahan pembelajaran untuk masyarakat dalam memanfaatkan teknologi dalam lingkungan sekitar.

Tujuan penulisan laporan KKN tematik Covid-19 Berbasis Ide Kreatif ini sebagai berikut :

1. Untuk mengedukasi masyarakat tentang pentingnya mencuci tangan sebagai pencegahan Covid-19.

2. Untuk mengembangkan fasilitas tempat cuci tangan otomatis sebagai pencegahan Covid-19.

Manfaat dari KKN Tematik Covid-19 Berbasis Ide Kreatif ini adalah sebagai berikut:

1. Bagi Mahasiswa

Sebagai latihan untuk menerapkan dan mempraktekan ilmu pengetahuan dan teknologi yang diperoleh selama perkuliahan.

2. Bagi Perguruan Tinggi

Sebagai tolak ukur pemahaman dalam mengaplikasikan ilmu pengetahuan dan teknologi selama perkuliahan.

3. Bagi Masyakarat/Pemerintah Daerah

a. Memperoleh bantuan ide/gagasan baru dan ilmu pengetahuan dalam merencanakan dan melaksanakan pembangunan.

b. Terjadinya peningkatan kesadaran masyarakat untuk selalu cuci tangan di masa pandemi ini

c. Untuk mengurangi dampak sentuhan dalam penggunaan tempat cuci tangan dengan banyak orang 
d. Sebagai bahan pembelajaran untuk masyarakat dalam memanfaatkan teknologi.

\section{METODE}

Desa Dangin Puri Kangin dibagi menjadi 7 wilayah yang terdapat banjar, tempat umum, tempat ibadah dan lain-lain. Dari pengamatan penulis, fasilitas tempat cuci tangan di tempat umum Desa Dangin Puri Kangin untuk pencegahan Covid-19 masih manual. Dalam penggunaannya bisa dikatakan belum 100\% aman karena akan menimbulan dampak sentuhan langsung pada gagang kran oleh penggunaan banyak orang. Dari permasalahan tersebut penulis mendapat solusi untuk mengembangkan tempat cuci tangan manual menjadi otomatis untuk meminimalisir sentuhan langsung pada kran. Dalam pelaksanaannya penulis akan membantu menerangkan pentingnya mencuci tangan dan mendiskirpsikan cara membuat tempat cuci tangan otomatis.

Penulis melakukan pengamatan di tempat umum yang biasanya dikunjungi warga sekitaran Desa Dangin Puri Kangin. Hal ini bertujuan untuk memastikan dimana tempat yang tepat diaplikasikannya tempat cuci tangan otomatis ini. Dari hasil pengamatan, tempat yang cocok diaplikasikan yaitu banjar, pasar dan pusat perbelanjaan.

Penulis melakukan sosialisasi secara online untuk meminimalisir kerumunan pada warga. Agar mempermudah dalam koordinasi, penulis membentuk grup whatsapp yang sebagaian besar anggotanya yaitu pemuda dan pemudi banjar Merta Rauh. Penulis dibantu dengan pemuda banjar menginfokan kepada warga yang bisa hadir untuk ikut serta dalam penyampaian materi melalui google meet.

Materi sosialisasi meliputi pemahaman tentang pentingnya mencuci tangan di tempat umum serta upaya pengembangan tempat cuci tangan otomatis untuk meminimalisir dampak sentuhan pada penggunaannya.

Penulis juga mencantumkan video di youtobe sebagai gambaran apabila sensor sudah terpasang di lapangan. Di video tersebut penulis mencontohkan bagaimana sensor bekerja di salah satu lokasi yang sudah menerapkan tempat cuci tangan otomatis. 


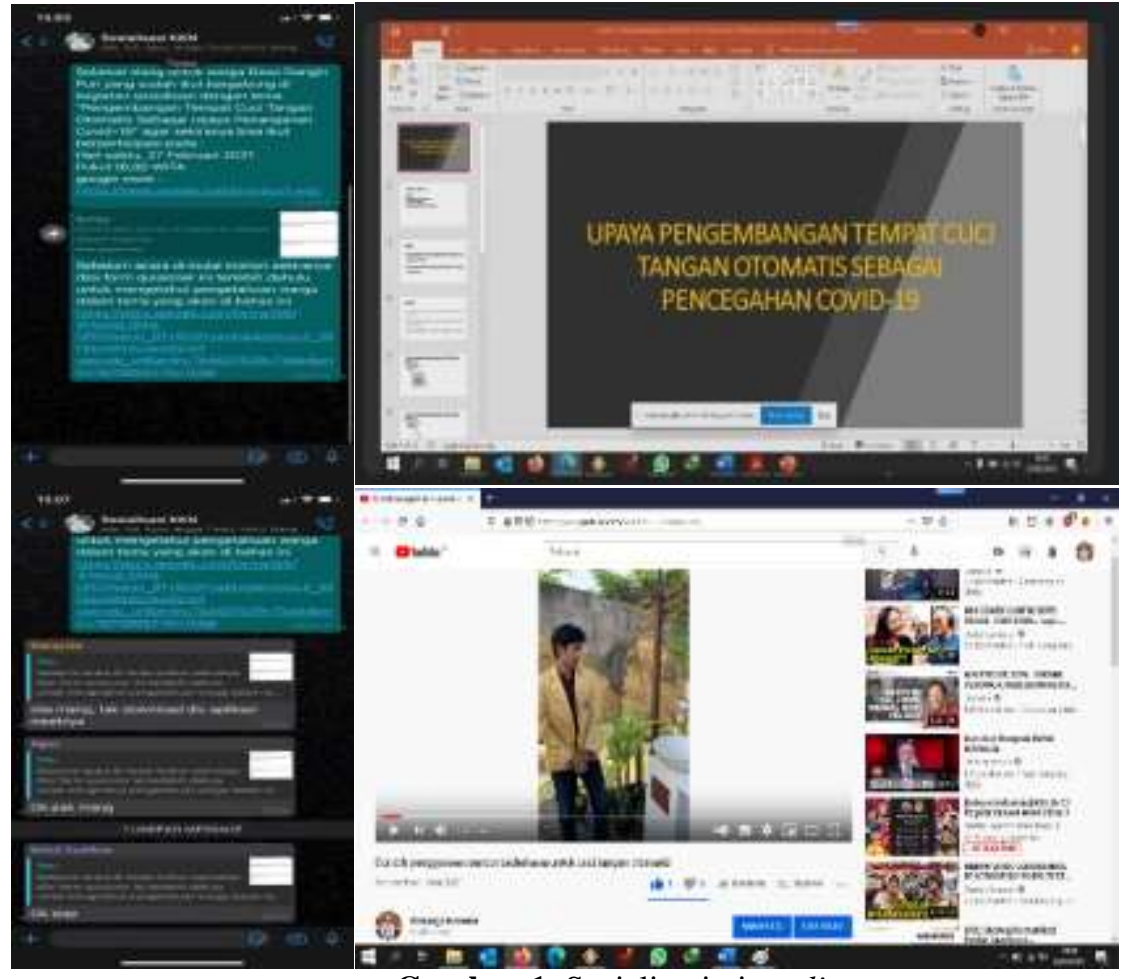

Gambar 1. Sosialisasi via online

Penulis memberikan diskripsi bagaimana cara mengaplikasikan tempat cuci tangan otomatis melalui gambar dan video. Penjelasan dalam pengaplikasian tempat cuci tangan otomatis dapat diuraikan sebagai berikut :

Dalam rencana pembuatan tempat cuci tangan otomatis ini, penulis menggunakan Sensor Automatic Water Sarver Tap dengan alasan karena sangat mudah diaplikasikan kepada masyarakat. Sensor ini menggunakan baterai di dalam perangkat yang akan bertahan selama 6 bulan dalam satu kali pengisian. Kemudian sensor ini juga tahan air jadi bisa digunakan di luar ruangan. Untuk menghubungkan kran dengan sensor, perlu menggunakan kran tipe zink yang memiliki drat di ujung kran. Dalam pemilihan wastafel sebagai wadah tempat cuci tangan bisa menggunakan jenis apa saja seperti wastafel aluminium, wastafel batu dan lain-lain.

Dalam pembuatan tempat cuci tangan otomatis diperlukan material pendukung seperti pipa untuk penyambungan antara kran dan sumber air. Keperluan pipa tergantung dari lokasi dimana tempat cuci tangan akan di pasang 
dan biasanya yang digunakan yaitu pipa aw 1/2", sock drat dalam 1/2", L bow 1/2", sambungan $\mathrm{T} 1 / 2$ ", ball valve $1 / 2$ ", lem pipa, gergaji besi, dll.

\section{Langkah Pengerjaan}

1. Tentukan lokasi pemasangan

2. Pastikan terdapat sumber air dan pembuangan pada lokasi.

3. Setelah menentukan tempat strategis, tempatkan wastafel dilokasi

4. Tutup sumber air sebelum penyambungan

5. Sambungkan sumber air menuju wastafel menggunakan pipa

6. Sambungkan pipa pembuangan pada wastafel

7. Pasangkan kran zink pada wastafel dan buka saringan pada ujung krannya.

8. Sebelum memasang sensor, isi daya sensor terlebih dahulu sampai penuh kemudian baru dipasangkan di ujung krannya.

9. Buka sumber air yang ditutup tadi dan pastikan tidak ada kebocoran di sepanjang pipa sambungan.

10. Jika sudah selesai tempat cuci tangan siap digunakan.

\section{Langkah Penggunaan}

1. Dekatkan tangan dengan sensor sejauh $5 \mathrm{~cm}$

2. Bila sensor aktif maka penutup/penghalang air dalam perangkat akan terbuka.

3. Air akan mengalir selama tangan masih mengalangi sensor.

4. Jika sudah selesai menggunakan dan tangan sudah menjauhi sensor maka penutup air pada perangkat akan menutup jalan air Kembali.

\section{Langkah Pemeliharaan}

1. Terdapat lampu pada sensor

2. Bila lampu menyala berarti baterai pada perangkat hamper habis.

3. Agar lebih aman, lepas terlebih dahulu sensor dari kran

4. Lakukan pengisian daya menggunakan adaptor yang sudah disediakan

5. Waktu pengisian daya kurang lebih 4 jam atau sampai lampu berhenti menyala yang menandakan pengisian sudah penuh.

6. Pasang kembali sensor pada kran. 
Kemudian penulis akan memberikan bantuan kepada warga yang ingin mengaplikasikan di rumah masing-masing atau di tempat umum namun belum begitu memahami cara pembuatan tempat cuci tangan otomatis ini.

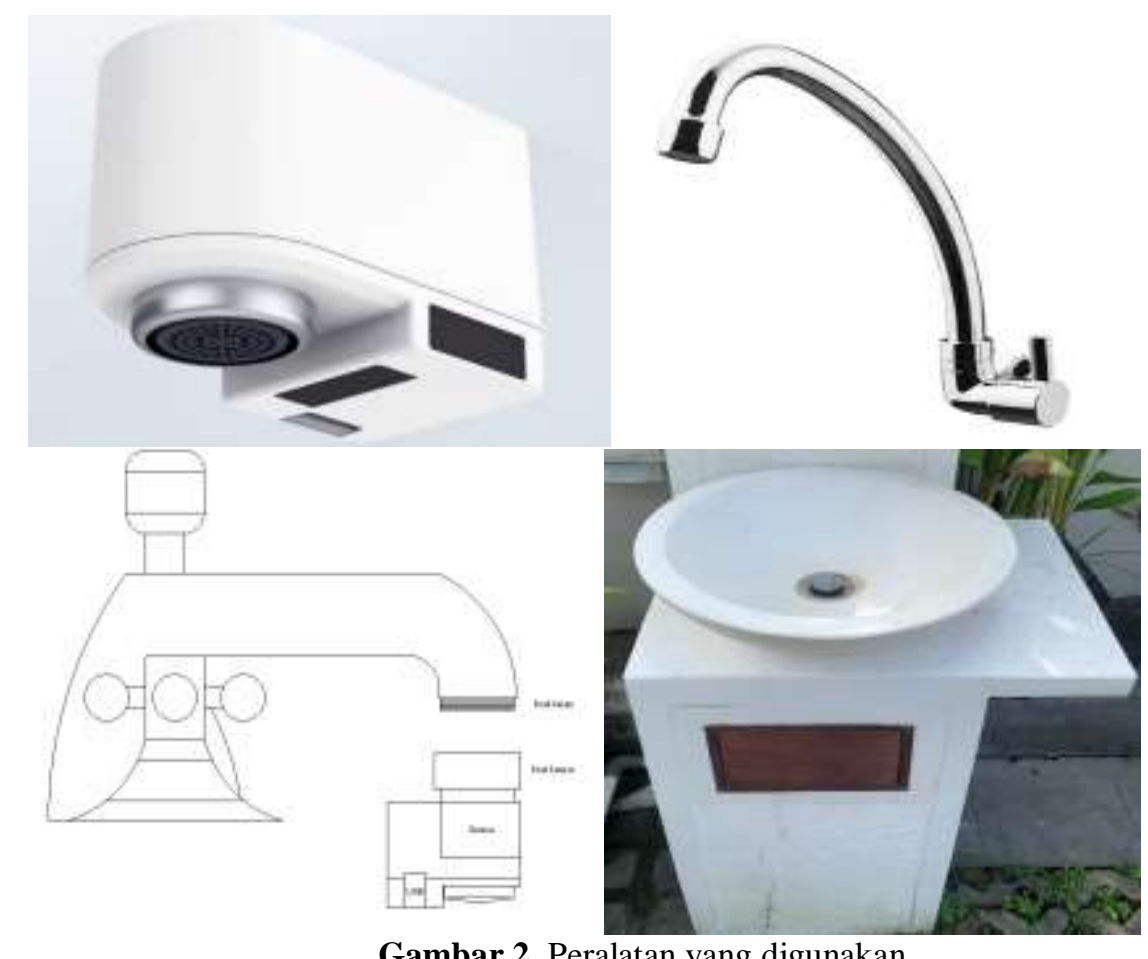

Gambar 2. Peralatan yang digunakan

\section{HASIL DAN PEMBAHASAN}

Sesuai dengan metode yang telah disampaikan, penulis telah membuat grup whatsapp yang anggotanya kebanyakan dari pemuda pemudi banjar. Penulis mendiskusikan permasalahan dan solusi yang penulis dapatkan kepada warga di grup whatsapp. Dari hasil diskusi penulis menjadwalkan pemberian sosialisasi bagaimana penerapan solusi via online/google meet. Untuk mengetahui tingkat pemahaman warga sebelum dan sesudah sosialisai, penulis memberikan kuisioner berupa google form kepada warga yang berada di grup. Kemudian berdasarkan pada pengamatan di lapangan, tempat cuci tangan yang berada di tempat umum di Desa Dangin Puri Kangin bisa dikembangan menjadi otomatis dengan diskripsi yang telah disampaikan pada metode. Adapun hasil dari sosialisasi dan pengamatan di lapangan, penulis membuat tabel sebulum dan sesudah pelaksanaan KKN sebagai berikut : 
Tabel 1. Perbandingan Sebelum dan Sesudah KKN

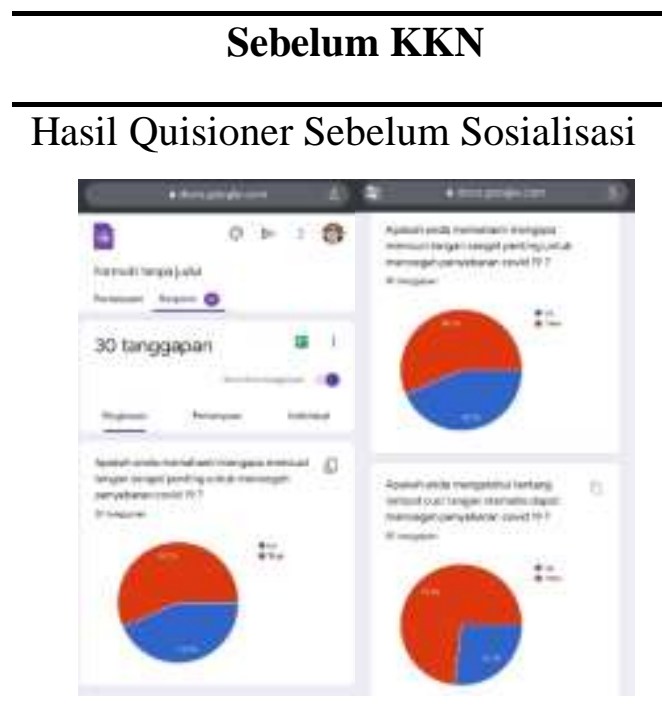

Penjelasan :

- Dari hasil kuisioner pada warga Desa Dangin Puri Kangin sebelum dilakukan sosialisasi terlihat sebanyak 56,7\% warga dari total 30 yang mengisi google form belum mengetahui pentingnya mencuci tangan di tempat-tempat umum selama pandemi ini dan 43,3\% sudah ada yang memahaminya.

- Selanjutnya hasil kuisioner untuk potensi pengembangan tempat cuci tangan otomatis sebelum dilakukan sosialisasi terlihat sebanyak $73,3 \%$ warga dari total 30 yang mengisi google form belum mengetahui tentang potensi tersebut dan $26,7 \%$ sudah ada yang mengetahuinya.

- Ini menandakan sebelum dilakukan KKN ini, sebagian besar masyarakat

\section{Sesudah KKN}

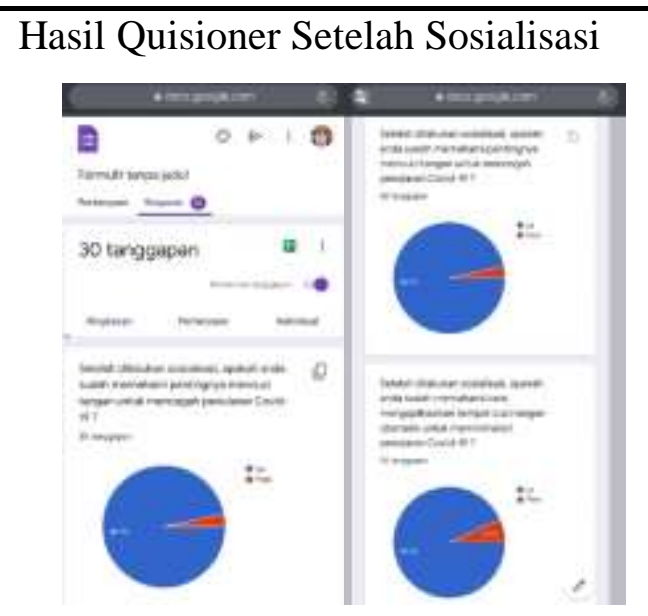

Penjelasan :

- Dangin Puri Kangin setelah dilakukan sosialisasi terlihat sebanyak $97,7 \%$ warga dari total 30 yang mengisi google form sudah memahami pentingnya mencuci tangan di tempat-tempat umum selama pandemi ini dan 3,3\% menjawab belum memahami.

- Selanjutnya hasil kuisioner untuk potensi pengembangan tempat cuci tangan otomatis sebelum dilakukan sosialisasi terlihat sebanyak $73,3 \%$ warga dari total 30 yang mengisi google form belum mengetahui tentang potensi tersebut dan $26,7 \%$ sudah ada yang mengetahuinya.

- Setelah di lakukan KKN setidaknya masyarakat sebagian besar sudah memahami tentang tema yang 
INTEGRITAS : Jurnal Pengabdian

Vol 5 No 1 Juli 2021

ISSN 2580 - 7978 (cetak) ISSN 2615 - 0794 (online)

\begin{tabular}{lllr}
\hline belum mengetahui tentang & disampaikan. & Semoga \\
pentingnya mencuci tangan dan & disebarluaskan dan dipraktekan di \\
mengembangan potensi tempat cuci & lingkungan sekitar. & \\
tangan bisa dibuat otomatis & & \\
\hline
\end{tabular}

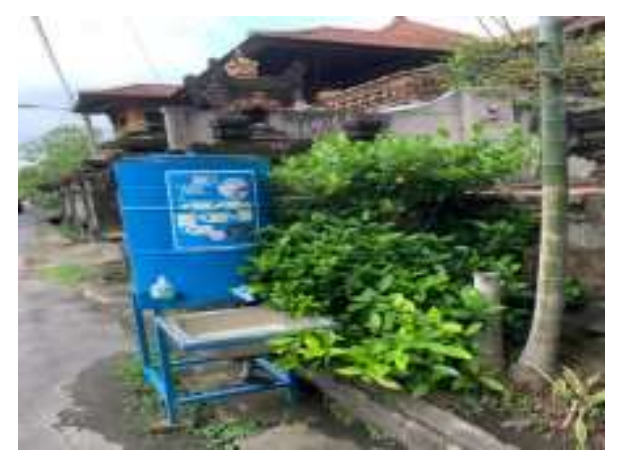

Pada tahap pengamatan, penulis

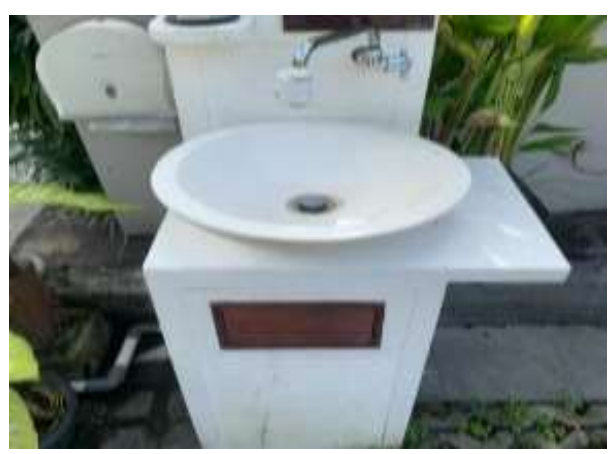

Setalah dilakukan KKN penulis

melakukan dokumentasi ke tempat- dapat mendiskripsikan bagaimana cara tempat umum yang berada di Desa mengembangkan tempat cuci tangan Dangin Puri Kangin. Bisa dilihat menjadi otomatis dengan sensor tempat cuci tangannya masih sederhana. Pada gambar terlihat menggunakan sistem manual. contoh hasil tempat cuci tangan yang Masyarakat pun banyak yang belum menggunakan sensor ini. Kemudian mengetahui tempat cuci tangan ini hasil dari diskripsi tersebut penulis bisa dikembangkan menjadi otomatis sosialisasikan kepada masyarakat untuk meminimalisisir penularan sebagai bahan pengetahuan yang Covid-19. nantinya bisa menjadi bekal bagi masyarakat bila ingin mencoba mengaplikasikan sensor ini.

Untuk mempermudah dalam melihat peningkatan pengetahuan warga selama sosialisasi, penulis membuat grafik sebagai berikut : 
INTEGRITAS : Jurnal Pengabdian

Vol 5 No 1 Juli 2021

ISSN 2580 - 7978 (cetak) ISSN 2615 - 0794 (online)

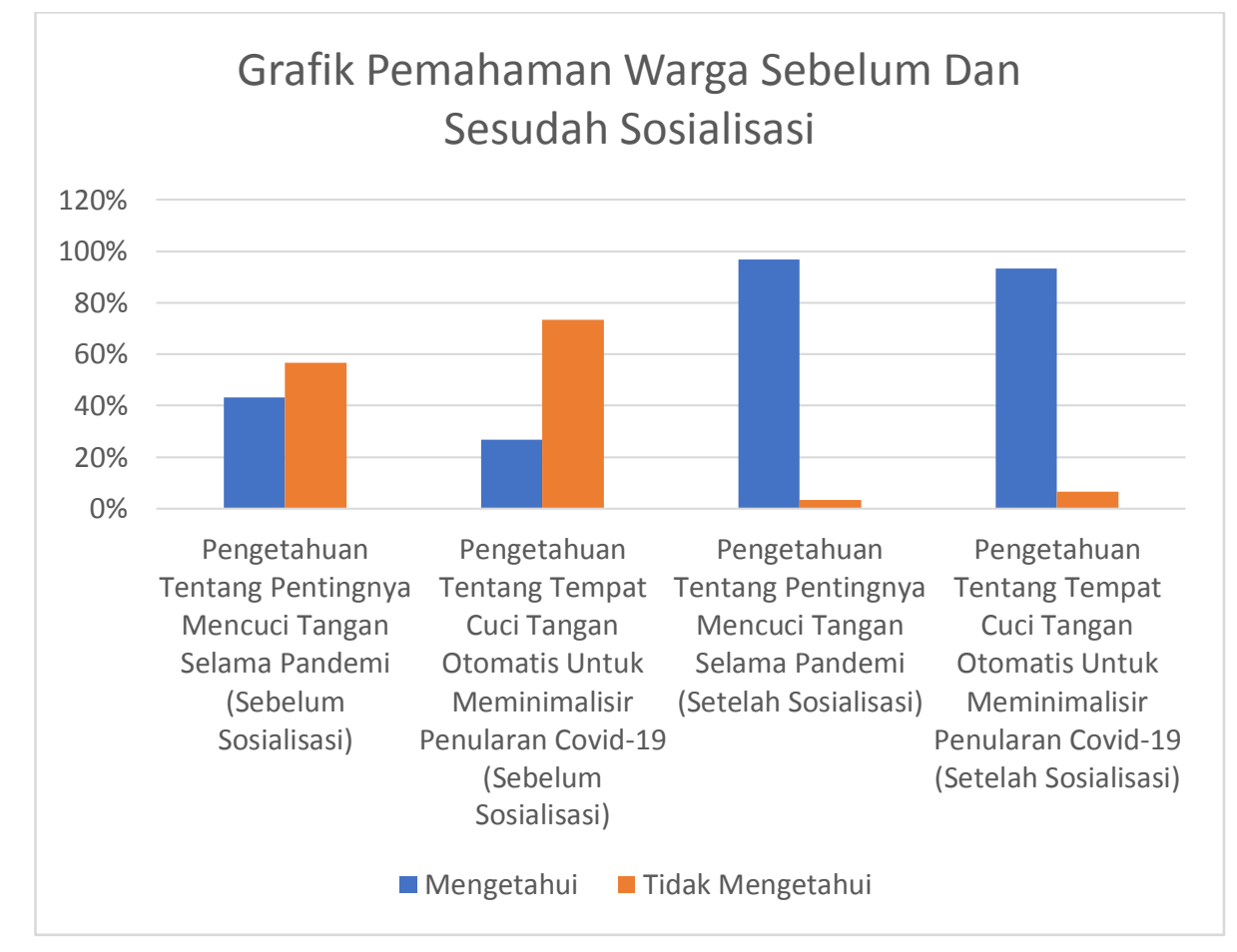

Gambar 3. Grafik hasil sosialisasi

\section{KESIMPULAN}

Dari hasil pembahasan sebulum dan sesudah pelaksanaan kegiatan ini dapat disimpulkan :

1. Dari persentase hasil kuisioner sebulum dan sesudah dilakukan KKN bisa dikatakan berhasil, ini terlihat sebagian besar warga sudah memahami sosilalisasi yang disampaikan.

2. Pengembangan tempat cuci tangan biasa menjadi otomatis bisa dilakukan dengan sesuai diskripsi yang telah disampaikan.

\section{UCAPAN TERIMA KASIH}

Kegiatan pengabdian ini berjalan dengan baik karena dukungan dari berbagai pihak, diantaranya Rektor Univerisitas Pendidikan Nasional, Kepala Lembaga Penelitian dan Pengabdian Kepada Masyarakat, Dekan Fakultas Teknik dan Informatika Universitas Pendidikan Nasional, Kepala Pengabdian, Dosen Pembimbing KKN, serta masyarakat khususnya Desa Dangin Puri Kangin yang telah ikut serta dalam kegiatan ini. Terima Kasih. 


\section{DAFTAR PUSTAKA}

Mardiani, Siti A., Hidayatullah, A., dan Sofa, M. Z. 2020. Edukasi Praktek Cuci Tangan Standar WHO dan Peduli Lingkungan. Jurnal Pembelajaran Pemberdayaan Masyarakat.

Suyetno, Agus.,Solichin., dan Nauri Imam Muda. 2020. Diseminasi Teknologi Alat Cuci Tangan Cerdas Higienis Sebagai Sarana Edukasi Pencegahan Covid-19 Di Desa Pakisjajar Kabupaten Malang.

Imaduddin, Ilmirrizki., Efendi, M. Fahrizal. 2020. Pembuatan Fasilitas Tempat Cuci Tangan Otomatis Sebagai Pencegahan Covid-19 Di Desa Paiton Kecamatan Paiton Kabupaten Probolinggo. Jawa Timur

dinkes.denpasarkota.go.id. (2021). Safe City Kota Denpasar [Online]. Tersedia pada https://safecity.denpasarkota.go.id/id/covid19 (19 Februari 2021)

diskes.baliprov.go.id. (2021). Provinsi Bali Tanggap Covid-19 [Online]. Tersedia pada https://infocorona.baliprov.go.id/ [19 Februari 2021].

oan.cl (2021). Xiaomi Induction Faucet Water Saver Infrared Sensor Water Saving Device [Online]. Tersedia pada https://www.oan.cl/xiaomiinduction-faucet-water-saver-infrared-sensor-water-saving-device/

Februari 2021]. 